NASA Technical Memorandum 100887

AIAA-88-2963

\title{
Small Engine Components Test Facility Turbine Testing Cell
}

(NASA-TH-100887) SMALL ENGINE COMPONENTS TEST FACILITY TURBINE TESTING CELL (NASA) $17 \mathrm{p}$

Brent C. Nowlin and Vincent G. Verhoff

Lewis Research Center

Cleveland, Ohio

Prepared for the

24th Joint Propulsion Conference

cosponsored by the AIAA, ASEE, ASME, and SAE

Boston, Massachusetts, July 11-13, 1988

\section{N/SA}


SMALL ENGINE COMPONENTS TEST FACILITY TURBINE TESTING CELL

Brent $C$. Nowl in and Vincent G. Verhoff

National Aeronautics and Space Administration

Lewls Research Center

Cleveland. Ohto 44135

\section{Abstract}

NASA Lewis Research Center has designed and constructed a new state-of-the-art test facllity. This facility, called the Small Engine Components Test Facility (SECTF), is used to test gas turbines and compressors at conditions simllar to actual engine conditions. The SECTF is comprised of two separate facilities - a turbine testing cell and a compressor testing cell. This paper will describe the turbine testing cell only.

The capabilities of the facillty make it unique - no other facllity of its kind is capabie of combining its pressure, speed, and temperature ranges. Turbine inlet air ranges up to $9 \mathrm{~atm}$ (125 psig). The turbine exhaust pressure ranges from $0.15 \mathrm{~atm}$ ( 2 psia) to atmospherlc pressure. Turbine inlet air temperatures range from amblent to $700 \mathrm{~K}\left(1260^{\circ} \mathrm{R}\right)$. The controllable speed of the turbine rotor ranges from 4000 to $60000 \mathrm{rpm}$ and the maximum power absorbed by the facillty dynamometer is $1250 \mathrm{hp}$. The data acquisition system scans up to 2000 channels/sec.

This paper will discuss in detall the capabilities of the facllity, overall faclility design, instrumentation used in the facllity, and the data acquisition system. Actual research data is not discussed.

\section{Introduction}

Small gas turbine engines producing up to $1200 \mathrm{~kW}$ ( $1600 \mathrm{hp}$ ) have become increasingly popylar in both the public and private sectors. Typlcal applications of these engines include milltary vehicles, power generators, and avlation. However, a small gas turbine engine is inherently less efficient than its larger counterpart. To study this reduced efficiency and the reasons behind it, NASA Lewis Research Center has designed and constructed a new test facility consisting of a compressor testing cell and a turbine testing cell.

The Small Engine Components Test Facllity (SECTF) is used to test the compressors and turbines for gas turbine engines at conditions similar to those found in normal use. The conditions are scaled such that the research pressures and temperatures are reduced, while the Mach number is the same as would be found in an actual engine. The capabilities of the facility make it unique no other facility of its kind is capable of combining its pressure, speed, and temperature ranges. Another point of interest is that either facility can be operated with only two people - one to operate the facillty and another to operate the data acquisition system. This paper will describe only the turbine facility.

The turbine facility control room is shown in Fig. 1. The facility operator's instrumentation and controls are shown in Fig. 2; the data acquisition system operator's instrumentation is shown in
Fig. 3. A photograph of the facillty test rig is shown in Fig. 4.

\section{Faclilty Alr Flow}

A schematic of the alr system of the turbine facility is shown in Fig. 5. The faclility uses air from a NASA Lewls 9 atm (125 psig) combustion air system. Combustion air at $14 \mathrm{~atm}$ (200 psig) is also avallable. The air enters the facllity through a $15.24 \mathrm{~cm}(6 \mathrm{in}$.) pipe. After passing through the inlet isolation valve, the flow enters a $7.6 \mathrm{~m}(25 \mathrm{ft})$ long, $15.24 \mathrm{~cm}(6 \mathrm{in.})$ diameter electrical resistance heater, rated at $250 \mathrm{~kW}$ $(14000 \mathrm{Btu} / \mathrm{min})$ of output heat. The temperature range of the heater is from ambient to $375 \mathrm{~K}$ $\left(675^{\circ} \mathrm{R}\right)$, and the heater system controllabllity is $\pm 1 \mathrm{~K}\left(1.8^{\circ} \mathrm{R}\right)$ at the heater exhaust.

Alr flow travels to the test cell through an insulated plpe. After passing through the inlet pressure control valve, the combustion alr enters a vitiating natural gas combustor. The temperature range at the combustor exit is from 422 to $700 \mathrm{~K}\left(760^{\circ}\right.$ to $\left.1260^{\circ} \mathrm{R}\right)$, with an overall controllabllity of $\pm 1 \mathrm{~K}\left(1.8^{\circ} \mathrm{R}\right)$. The combustion air then enters the research turbine.

After passing through the research turbine, the air passes through the exhaust pressure control valve and into either the laboratory altitude exhaust system or the atmospheric exhaust system. For turbine exhaust pressures from 0.15 to $1 \mathrm{~atm}$ ( 2.2 to $14.7 \mathrm{psia}$ ), the altitude exhaust system is used; for turbine exhaust pressures of $1 \mathrm{~atm}$ (14.7 psia) or higher, the atmospheric exhaust system is used. A water spray ring, located downstream of the exhaust pressure control valve. controls the temperature of the exhaust air before it enters elther exhaust system.

The inlet pressure is controlled by a modulating globe valve, and the exhaust pressure is controlled by a butterfly valve. The valve controllers allow each valve to be operated either by setting the valve position (manual operation) or by setting the pressure assoclated with the valve (automatle operation). The position or pressure associated with each valve are input to their respective controllers, whlch allows the controllers to constantly adjust each valve position as conditions change. A $150 \mathrm{~atm}(2200 \mathrm{ps} / \mathrm{g}$ ) hydraulic system drives the valves to the correct position.

\section{Rotating Equipment}

The rotating equipment in the facillty consists of the turbine rotor, an In-line torquemeter, a speed-reducing gearbox, and an eddy-current dynamometer. The torquemeter shaft is connected to the gearbox. which has a gear ratio of $2.735: 1$. The gearbox transfers the generated power to the dynamometer. 
The torquemeter has three interchangeable shafts which enable it to meet the speed and torque ranges needed for a given test. Selecting the appropriate shaft provides improved accuracy over the entire torque range. Torque ranges for the individual shafts are nominally 0 to $108 \mathrm{~N}-\mathrm{m}<0$ to $80 \mathrm{ft}-1 \mathrm{~b}), 0$ to $305 \mathrm{~N}-\mathrm{m}(0$ to $226 \mathrm{ft}-1 \mathrm{~b})$, and 0 to $576 \mathrm{~N}-\mathrm{m}$ ( 0 to $427 \mathrm{ft}-1 \mathrm{~b}$ ). The interchangeable shafts allow the torquemeter to maintain a measured torque accuracy of 0.1 percent of the full-scale torque of that particular shaft. The torquemeter transducer is shown in Fig. 6 .

In addition to measuring the torque, the torquemeter also measures speed. If desired, the torquemeter can be conflgured to display speed and power. The torquemeter multiplies the measured speed and torque to obtain the power. Speed is measured using a magnetic speed plckup. Torque is found by solving the following equation:

$T=C x(\theta-$ zero offset $)$

In this equation. $T$ is the torque, $C$ is the shaft stiffness, $\theta$ is the phase difference of speed signals at opposite ends of the shaft, and zero offset is the reading on the torquemeter when the shaft is unloaded.

The dynamometer controls the speed and absorbs the power generated by the research turbine. Digital control is used in the dynamometer, and its controllable speed range is from 1500 to $25000 \mathrm{rpm}$, controllable to $\pm 10 \mathrm{rpm}$. The power absorbed by the dynamometer may range up to $935 \mathrm{~kW}$ $(1250 \mathrm{hp})$. The gearbox allows the turbine rotor speed to range from 4000 to $60000 \mathrm{rpm}$. The dynamometer also has the capability to control the acceleration or deceleration of the rotor. The torquemeter, gearbox, and dynamometer are shown in Fig. 7 .

The iubrication systems for the rotating machinery are monitored for flow, temperature, and pressure. With the exception of the research turbine and torquemeter, each module has its own separate lubrication system. The turbine and torquemeter share a common pump and reservoir. Each system also has a backup pump in case the primary pump fails. The backup pumps are driven by an auxfliary air system, and are automatically engaged by a low pressure switch.

A thrust balance system is used to maintain the rotor bearing preload by pressurizing a balance piston mounted on the rotor shaft. An auxiliary air system is used to pressurize the balance piston. This system uses the balance piston supply pressure and the pressure drop across the rotor as inputs. The output of the system is the position of the thrust balance piston.

\section{Data System}

Research data acquisition is accomplished by using a distributed data acquisition system, which allows the facility computer hardware to scan up to 2000 channels/sec. Existing computer hardware in the facility allows up to 512 analog channels and approximately 1500 other channels to be scanned. Among the analog channels are thermocouples, actuator positions, torquemeter data, tip clearance measurements, pressure transducers, and frequencyto-de converters. Among the other input channels input to the facllity computer are pressures read from an electronically scanned pressure system.

Temperatures are measured using thermocouples. The cold function compensation is made using thermocouple reference blocks, each block nolding up to 48 thermocouple junctions. Temperature-sensitive platinum resistors embedded in the reference blocks are used to correct for the transition from thermocouple alloy to copper. Currently six blocks are installed, allowing 288 temperatures to be measured.

Probe actuators are used to obtain a profile of pressures, temperatures, and, if destred, flow angle across a region. A pressure probe or thermocouple is mounted on a probe actuator: If flow angle is measured as well, a yaw probe is mounted on the probe actuator in addition to the pressure probe or thermocouple. The probe actuator controller continuously rotates the yaw probe until the pressure difference across the probe measures zero, which occurs when the probe is pointing directly into the flow. The probe actuators are stepped across a region automatically, using predetermined setpolnts. The data for each point is stored in the data system.

Parameters dealing with the rotating turbline wheel itself are equaliy important. A torquemeter, mentioned before, provides the data system with torque and speed signals. The rotor tip clearance is monitored using touch probes. When the rotor reaches sufficlent speed, the touch probe controller recelves a permissive. This permissive, when combined with an operator-controlled pushbutton interlock, enables the controller to automatically advance the probes toward the blades of the rotating rotor. When the probes are sufficiently close, the probes send a low energy arc across the alr gap between the probe tip and rotor blade. When the probe controllers sense the arc, they display the gap in mils and provide an and log signal representing the gap. The controllers then retract the probe to the datum position, which is even with the turbine casing wall. The probes then continuously advance, arc, and retract. This process continues until it is el ther halted manually (operator inter vention), by the speed dropping below the setpoint (loss of permissive), or by an emergency shutdown.

Pressures measured by discrete transducers are aiso used in the data system. Among these pressures are the reference, check, and control pressures for the pressure scanning system. Also included in the discrete pressure transducer list are pressures monitoring operating conditions such as lubricating 011 pressures, thrust balance pressures, water pressures, and auxillary alr system pressure.

Most flows are measured using turbine flowmeters. Among these are lubrlcating oll and natural gas flows. The facillty inlet air flow, which is a research parameter, is calculated from pressures across a calibrated venturi.

\section{Pressure System}

The electronically scanned pressure system is used for measuring large numbers of research pressures. Currently, the system contains six sensor modules of 32 channels each, for a total of 192 channels. This number can be increased to a 
maximum of 1024 channels by adding additional pressure modules. Each channel in each module has its own differential pressure transducer. Currently, all transducers in the pressure system are \pm 3 atm $( \pm 45 \mathrm{psi})$ differential. The sensor modules are controlled by the pressure system data acquisition and control unit (DACU). The DACU also controls the pressure calibrate unit, which allows on-line calibration of the modules. A block diagram of the pressure system is shown in Fig. 8, and a block diagram of the DACU is shown in Fig. 9.

The pressure scanning system is able to calibrate itself automatically during a test run. The time interval between callbrations is user-

specified, typically $20 \mathrm{~min}$. After the time perlod (which is displayed on the facllity CRTs) expires. the pressure calibrate unlt uses known pressures to recalibrate itself, thus enabling the pressure scanning system to always maintaln a system accuracy of 0.1 percent.

The sensor module transducers are callorated by applying known pressures of $0.68,2.04$, and $3.4 \mathrm{~atm}(10,30$, and $50 \mathrm{ps}(\mathrm{a})$ to the transducers and calculating the necessary coefficlents for each individual transducer. The calloration pressures are measured by precision quartz transducers. A pressure of $1.02 \mathrm{~atm}(15 \mathrm{ps} 1 \mathrm{a})$, applled to the reference side of the sensor module transducers, allows the pressure system to measure a range from 0.15 to $4 \mathrm{~atm}(2.20$ to $58.8 \mathrm{ps} / \mathrm{a})$. The OACU generates a linear curve fit for this range using the electrical signals obtained from the calibration. The DACU matches the measured pressures (that is, the electrical signals generated by each pressure transducer in the sensor modules) to the pressure curve generated during callibration. A $2.72 \mathrm{~atm}$ (40 psia) pressure is used as a known check pressure to verify proper system operation.

The electrical signals of the pressure system are multiplexed into a desktop computer, which performs the numerical analysis and packaging of the data before sending it to the facillty host computer. The desktop computer also acts as a master to the pressure system. Electrical multiplexing of the pressure signals enables the system to acqulre the pressure data much faster than if pneumatic multiplexing is used.

\section{Facility Data Acquisition}

A block diagram of the data system is shown in Fig. 10. Analog inputs to the system range from $5 \mathrm{mV}$ to $10.24 \mathrm{~V}$ full scale. The slgnals are multiplexed and then amplified to the $10.24 \mathrm{~V}$ level. The multiplexed, amplifled signals are then input to an analog-to-digital converter (ADC). A digitizer is used for the multiplexing, amplifying, and $A D C$ of the analog signals. The $A D C$ is 13 bit plus sign, giving a full scale binary value of -8191 to +8191 . The data from the ADC is then passed to an input/output interface unlt, which uses the IEEE- 488 bus to transfer the digitized data to the host computer. The interface unit also has the features of frequency-to-digltal conversion, relay outputs, digital-to-analog conversion, an input isolated latch, and a TTL Input latch. The signals generated from these input/ output modules are multiplexed to the interface unit bus.
The facllity host computer converts the data from the interface unit, which is in millivolts. to engineering units. Several standard conversion rules are avallable, as well as user-defined curve fits. In addition to the conversion rules from millivolts to engineering units, each parameter may be post-converted. Post conversion allows the operator to observe and record the data in any desired form.

The data is displayed in real-time by using CRTs with a numerical entry panel as an operator interface. Important parameters are displayed on individual digital displays (IDOs), which enables the operators to monitor these parameters more easliy. CRT and IDD update time is once per second. Related data, both measured and calculated, is put into a page format and the pages are then selected for viewing on the CRTs by the operators. A printout of any CRT screen may be generated at any time. Real-time data display enables problems to be Identified whlle the run is stlll in progress, which allows the operators to be aware of and correct problems before the data is recorded. This abilIty in the data system saves both time and energy. The real-time monitoring of operating conditions is desirable with rotating equipment because it provldes a warning of Impending damage prior to the damage occurring. Thus, the operator can take corrective action to prevent many problems.

On-line calculations are performed on the measured parameters, and are avallable for display along with the measured parameters. Examples of calculated parameters include pressure ratio across the turbine, air flow, lubrication oll flow, and average pressures across a region. On-line calculations are desirable because this data is valuable for specifying and maintaining test conditions and provides on-line facllity operating parameters.

If, for some reason, a channel is not valld, the data system allows the operator to attach a software tag to that channel (code out). Coding out a channel prevents that channel from being used in any calculations Involving it. An example of an Invalld channel would be a defectlve sensor. Coded out channels are stlll updated and can be coded in at any time. Varlous levels of codeouts are avallable and allow for different methods of managing the calculations involving any coded out channel. The different ways of handling codeouts enable the data system to maintain meaningful calculations. A channel may also be substituted for another channel or be forced to a certain value, and the substituted for forced value will be used in the calculations involving that channel.

Pre-selected channels and calculations are checked for limit violations. If a parameter is outside of the allowable range assigned to $1 t$, the channel is displayed in reverse video on the CRTs. In addition to displaying the channel in reverse video, a CRT page may be created which displays a)l channels in limit violations. A CRT screen of this type of page is shown in Fig. 11 . If desired, alarms and shutdowns may be triggered from limit violations. Currently, all shutdown situations are triggered from hardwired systems external to the data system. Thus, if the data system falls, the faclilty is stlll protected against potentiaily dangerous situations. 
The data system creates a history file, which contains a block of all parameters in the data system over a specified time. The history flle is continuousiy updated during the run. A significant event such as high turblne vibrations will prevent updating, or "freeze." the history file. The significant event is user-specifled. Freezing the history file creates a permanent record of the parameters before and/or after the signiflcant event. The length of time before and after the significant event is user-specifled. Up to three history files may be created. If a fallure does occur, the history flle may be examined and the events leading up to the fallure can be identified.

A simulation file may also be created by the user. This file contains user-defined values for the data system parameters, and 1.5 usually created off-line. The data system is capable of comparing on-line parameters to the parameters in the simulation file. All measuring devices, as well as operating conditions, may be checked elther before or after the run by this comparison. The simulation file is also useful for training operators and verifying software modifications.

Frequently used commands in the data system are incorporated in a pushbutton entry panel. This panel communicates to the data system via the RS-232C interface. Among the commands avallable on the panel are: store the current data, step the actuators through their cycle and store the data, calibrate or prevent calibration of the electronically scanned pressure system, freeze the history $f i l e(s)$, and others. The function of each button is user-definable, and can be changed at any time. The panel allows easy operation of the data system and gives manual control of some of the data system's normally automatic functions.

Also included in the data system are a 71 megabyte hard disk drive, an 800 kllobyte dual floppy disk drive, and a 95 megabyte streaming tape drive. These devices all communicate with the facility computer over the IEEE-488 bus, and are used to store all data readings taken by the data system. In addition to storing the data locally in the facllity, the readings are sent (vla the RS-232C Interface) to a central computer for storage and post-processing. The data system can be easily reconflgured to comply with secure testing guidelines.

\section{Facility Safety Instrumentation}

The operating conditions of the facility are monitored by systems other than the data acquisition system. Meter relays display bearing temperatures of the research turbine, torquemeter. gearbox, and dynamometer. Electric heater exit temperature, combustor exit temperature, and turbine inlet and exhaust temperatures are also monitored by meter relays. All meter relays in the facility have two setpoints: the first is used to trip a warning annunciator should the temperature monitored by a particular relay rise above a "caution" point: the second is used for an emergency shutdown should a temperature rise above the safe temperature for that particular parameter.

Shaft displacement is measured by proximity probes. Two probes in the same plane are located $90^{\circ}$ apart, which gives the instantaneous movement in both the $x$ - and the $Y$-directions. These signals are input to oscllloscopes, which allows an accurate representation of the orblts of the shafts to be observed. The shaft displacements cannot directly trigger an emergency shutdown; if the orblts become too large, the vibrations wlll be transmitted to the bearings.

Bearing vibrations are monitored using accelerometers. The vibration levels initlate an annunclator if operator action is required to correct a potentlally hazardous situation, and initiate an emergency shutdown if the vibration levels become dangerously large. A permanent record of the vibration patterns are saved on tape using an analog tape recorder. The rotor speed and the time code (a signal containing time-of-year information) are recorded along with the vibration patterns. If a problem occurs, the tape wlll provide a recorded history of the amplitude and frequency of the vibration channels for post-fallure analysis.

Shutdowns avallable on the torquemeter are overtorque, overspeed. excessive rate of change of torque, and excesslve rate of change of speed. overspeed shutdown is currently obtained from a speed relay instead of the torquemeter. The dynamometer shutdown string is separate from the facllity shutdown string. Each string is interconnected to the other, however, so that in the event of a dynamometer shutdown, the facllity will shut down. and if the factlity shuts down, the dynamometer will shut down. The facility is designed in this way to protect against a shaft or coupling break and turbine overspeed. These are two primary safety concerns with rotating machinery, and in elther case, the entire faclilty must be shut down in an orderiy but expeditious manner.

When starting, net ther the facllity interlock in the dynamometer shutdown string nor the dynamometer interlock in the faclility shutdown string is closed, thus the whole system is in a shutdown state. To be able to start, one of the Interlocks must be overridden. A speed monltor is used to override the dynamometer interlock below $1000 \mathrm{rpm}$. which enables the rotor to start rotation. The facllity is also protected agalnst loss of speed signal to the overspeed relay and the speed monitor.

Most of the faclilty relay logic outside of the torquemeter and speed relays is incorporated in a programmable controller. This allows greater flexiblifty in the loglc and saves space that would otherwise be used by relays. All facllity shutdowns (except overspeed and torque-related shutdowns, manual emergency shutdown, and dynometer-initiated shutdowns) are derived from the programmable controller. The programmable controller also drives warning annunclators, which are caused by faults in the lubricating ofl systems, unsafe combustion air conditions, and mechanical problems in the research turblne. Any unsafe operating condition causes a warning annunclator first. so that the operator has a chance to correct the situation before going into an emergency shutdown. The facllity has the capabllity for 96 total annunclator channels.

An emergency shutdown leads to several events occurring simultaneously. The dynamometer increases its fleld current to bring the shaft to 
a stop. The inlet air valve closes (full stroke $100 \mathrm{~ms}$ ), while the exhaust valve is sent to the full open position, so that any pressure remaining in the turbine cavity is vented. After a specified time, the dynamometer field current drops to zero to prevent overheating of the dynamometer field coils. The dynamometer must be reset before a restart is attempted. Of course, the problem that led to the emergency shutdown must be identified and remedied. The electric heater and natural gas combustor are also shut off if an emergency shutdown occurs.

\section{Summary}

The turbine facility of the SECTF has been operational since June 1987, and the compressor facility has been operational since August 1987 Thus far, research data has been considered excellent. The research data acquisition system used in the turbine facility has now been installed in seven other facilities. Operation of the SECTF has been excellent as well, mostly due to the facility's overall design.

OXIGNTAI PEGM IS
OF POC

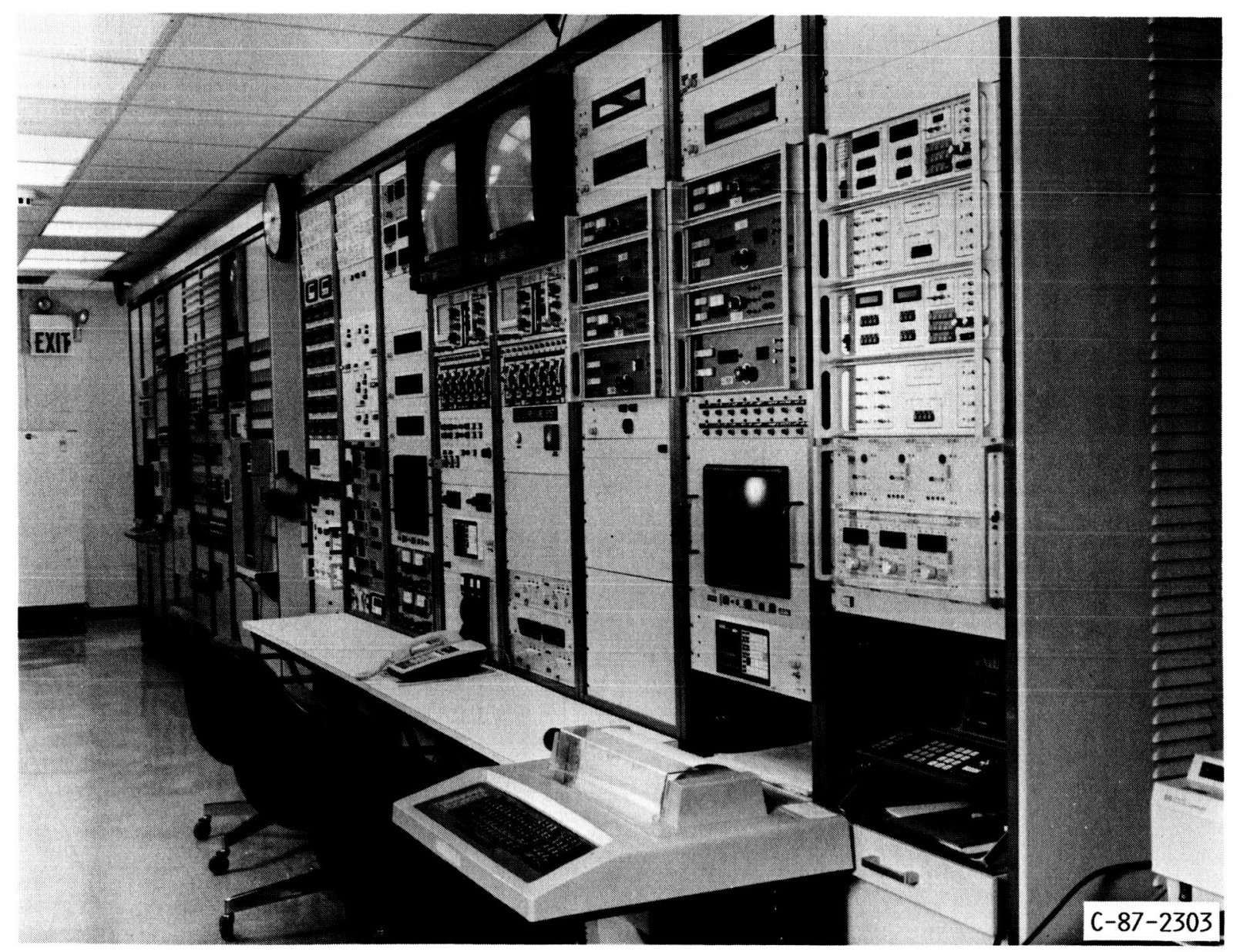

FIGURE 1. - TURBINE FACILITY CONTROL ROOM. 


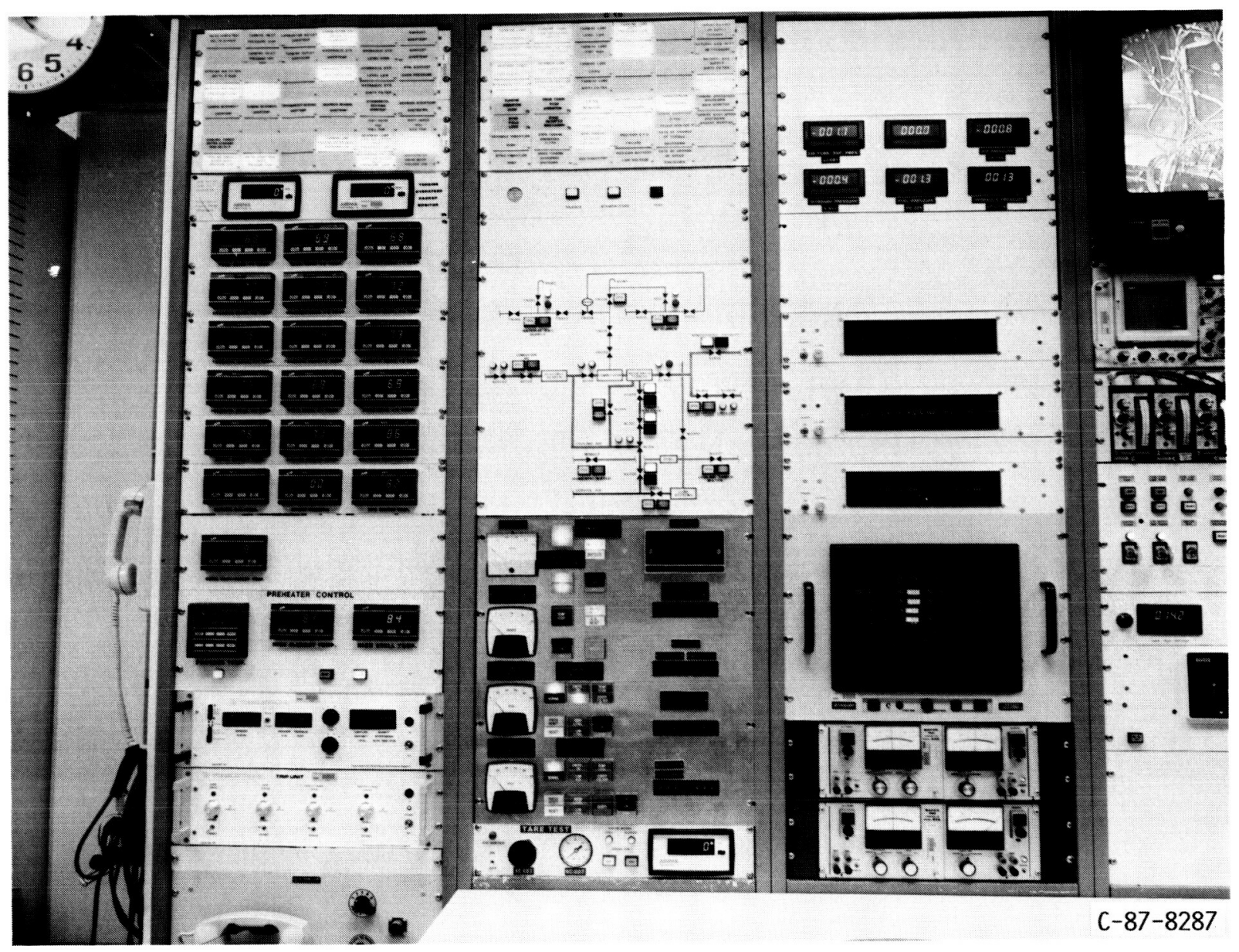

FIGURE 2. - FACILITY OPERATOR'S INSTRUMENTATION AND CONTROLS. 
ORIGNAL PAGE IS

OE POOR QUALITY

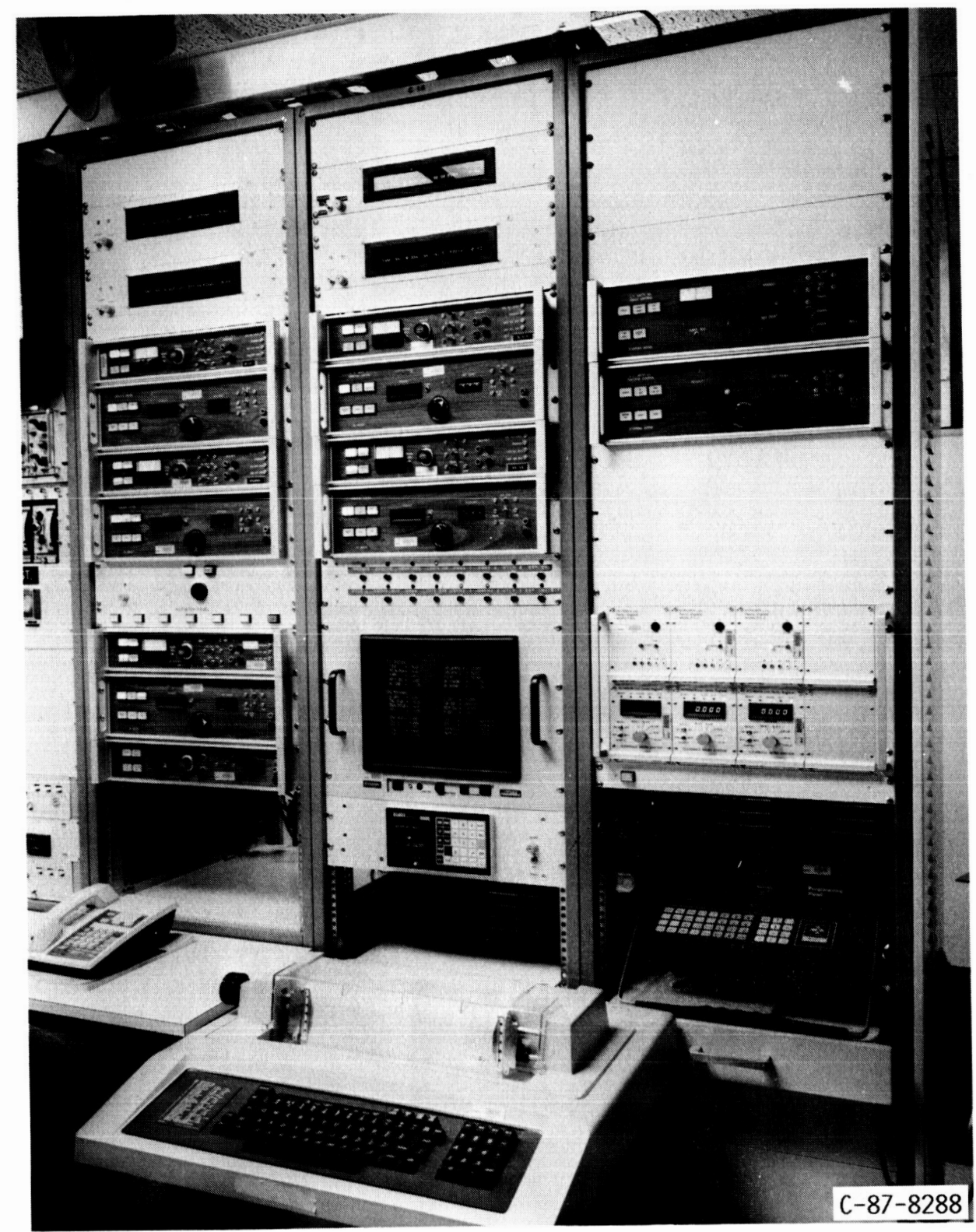

FIGURE 3. - DATA ACQUISITION SYSTEM OPERATOR'S INSTRUMENTATION AND CONTROLS. 


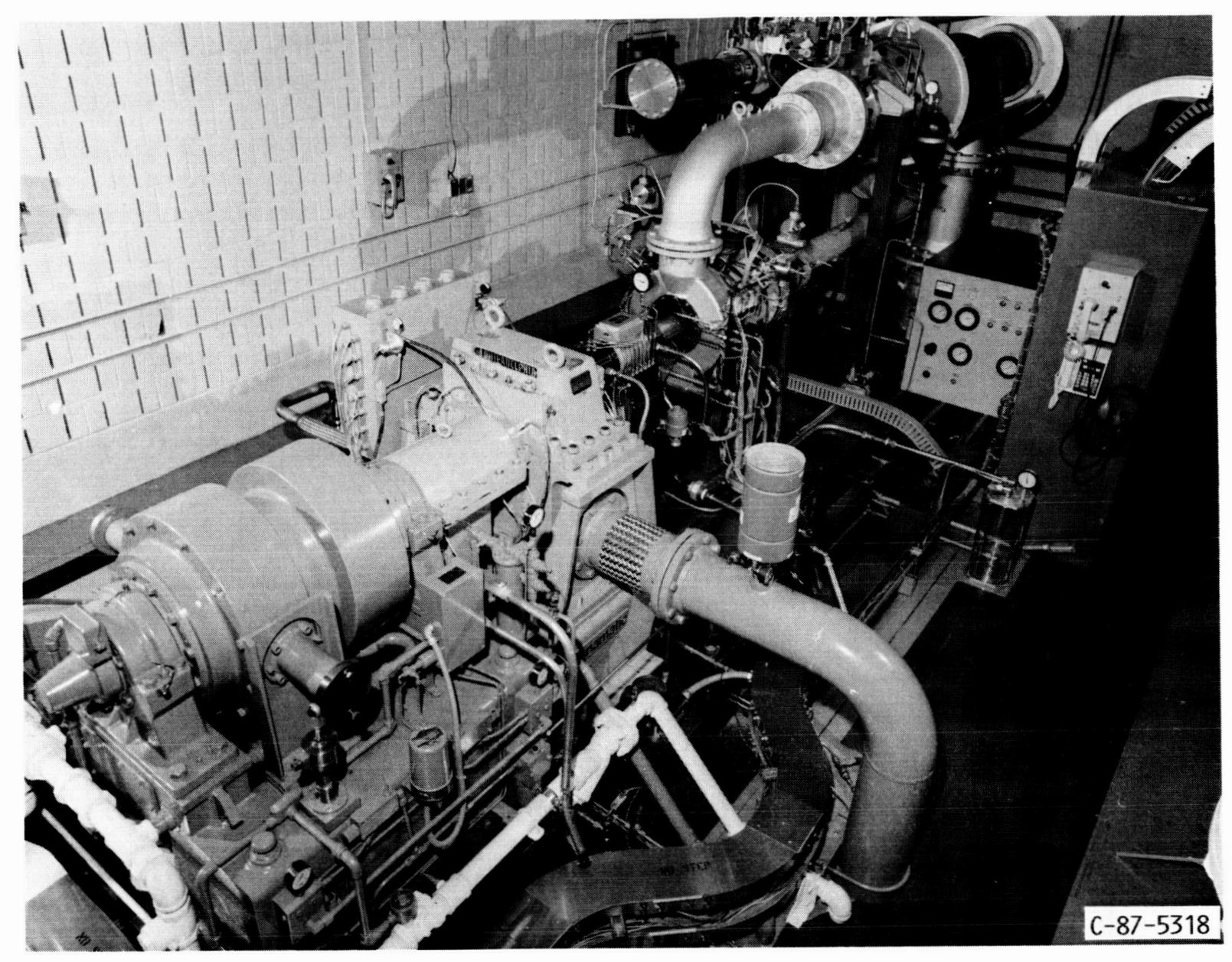

FIGURE 4. - FACILITY TEST RIG.

ORIGINAL PAGE IS
OF POOR QUALITY 


\section{SMALL WARM TURBINE TEST FACILITY}

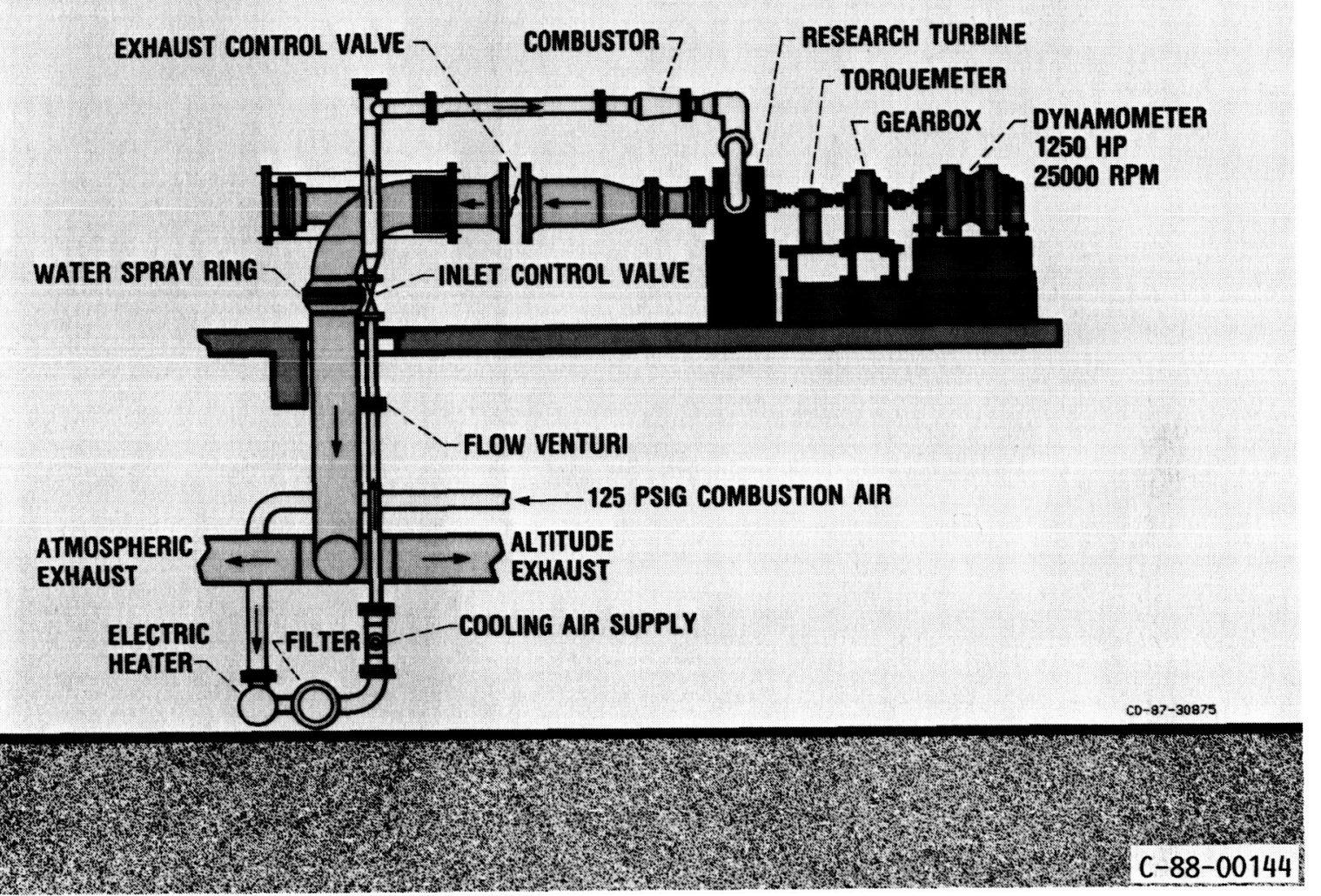

FIGURE 5. - AIR SYSTEM SCHEMATIC. 


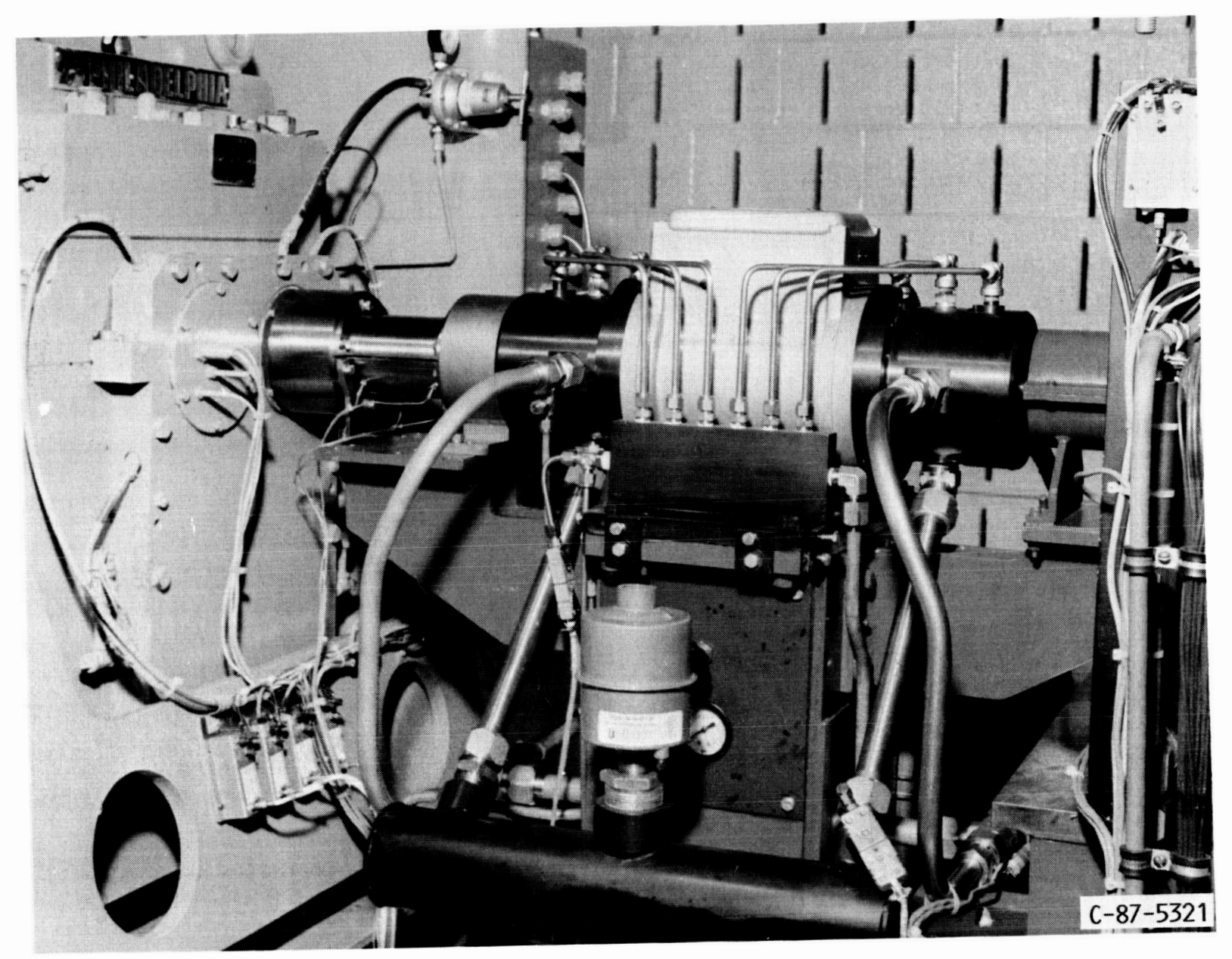

FIGURE 6. - TORQUEMETER TRANSDUCER.

ORIGINAL PAGE IS

OE POOR QUALITY 


$$
\begin{aligned}
& \text { ORIGINAL PAGE IS } \\
& \text { OF. POOR QUALITY }
\end{aligned}
$$

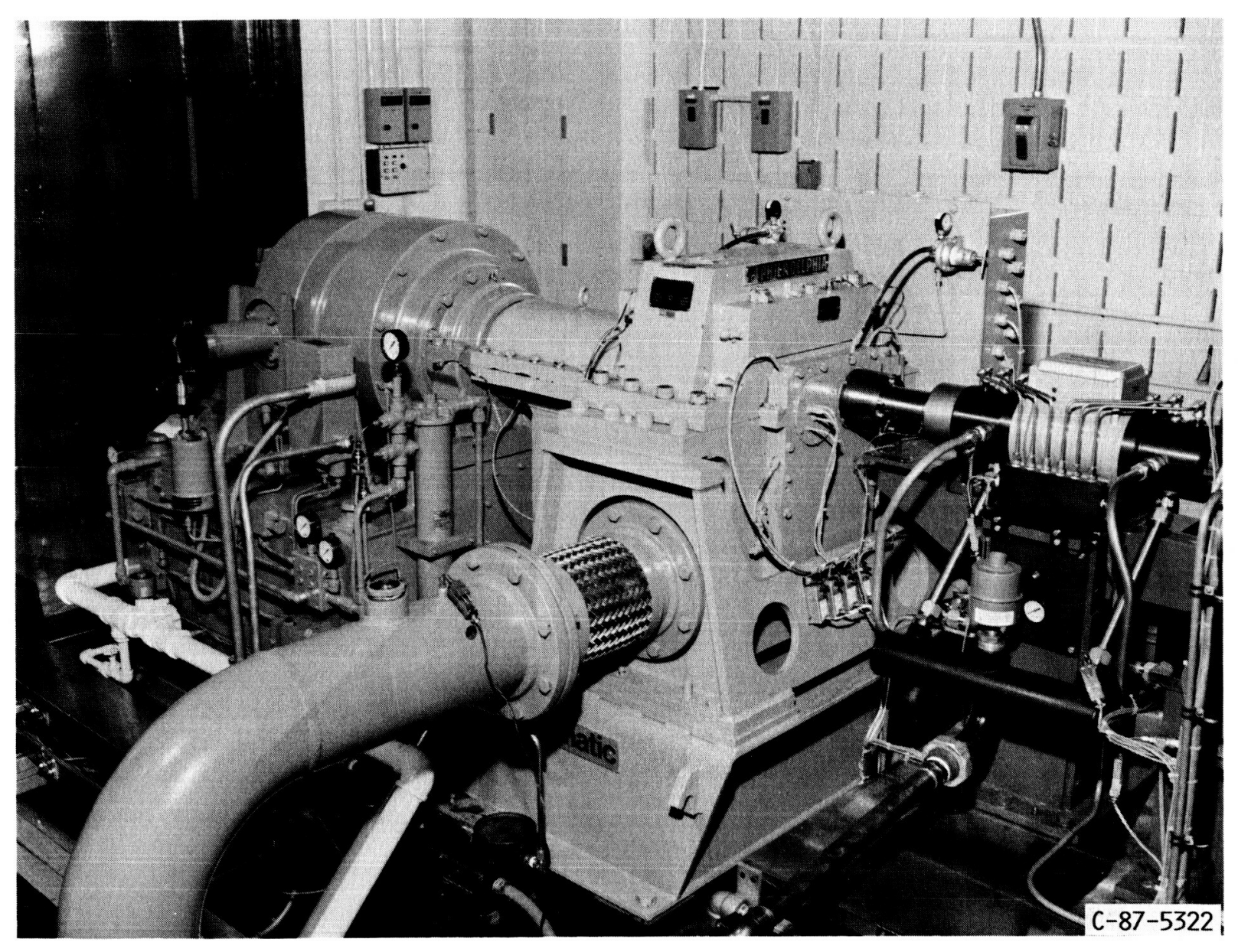

FIGURE 7. - TORQUEMETER, GEARBOX, AND DYNAMOMETER. 


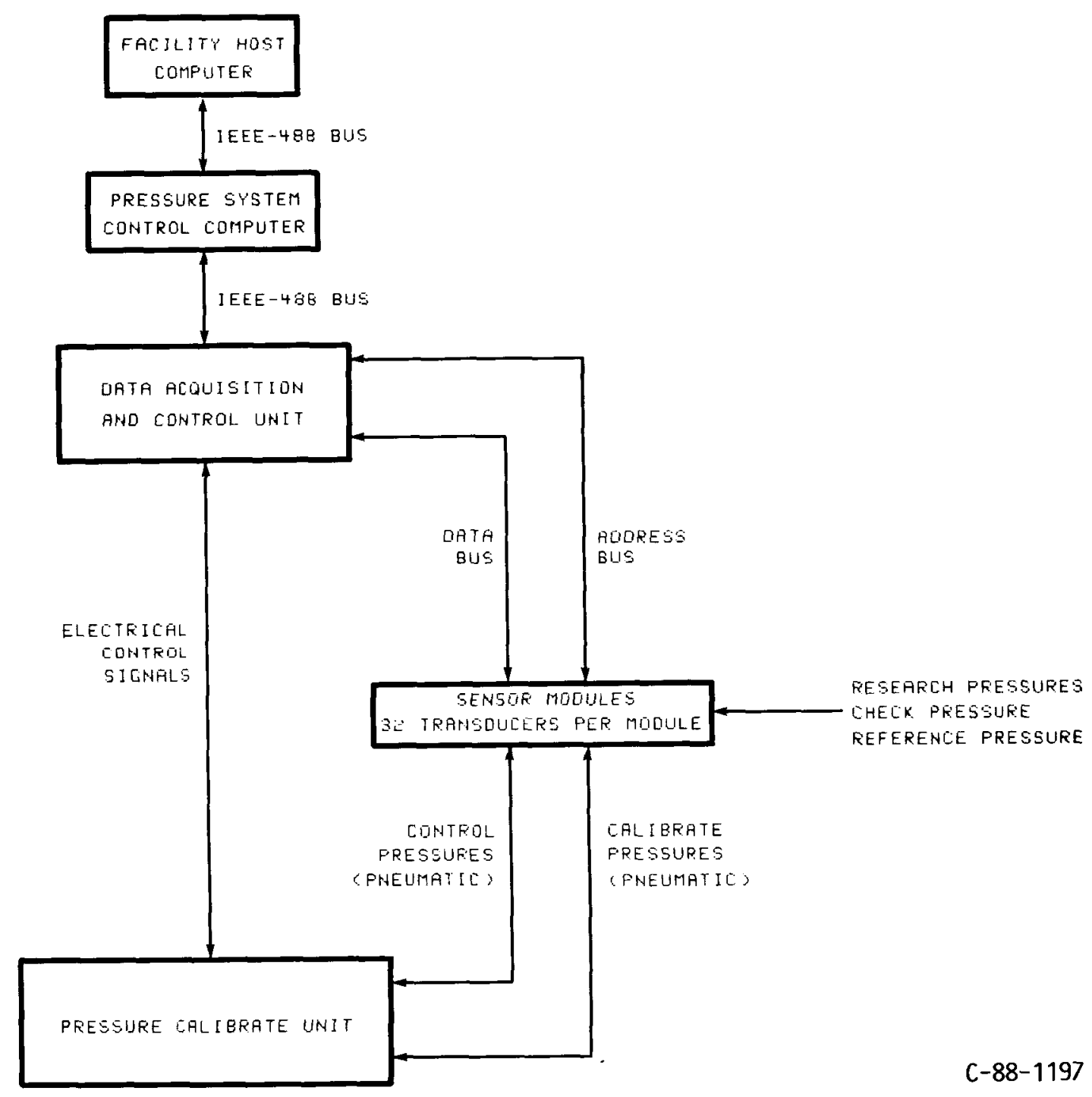

FIGURE 8. - ELECTRONICALLY SCANNED PRESSURE SYSTEM. 


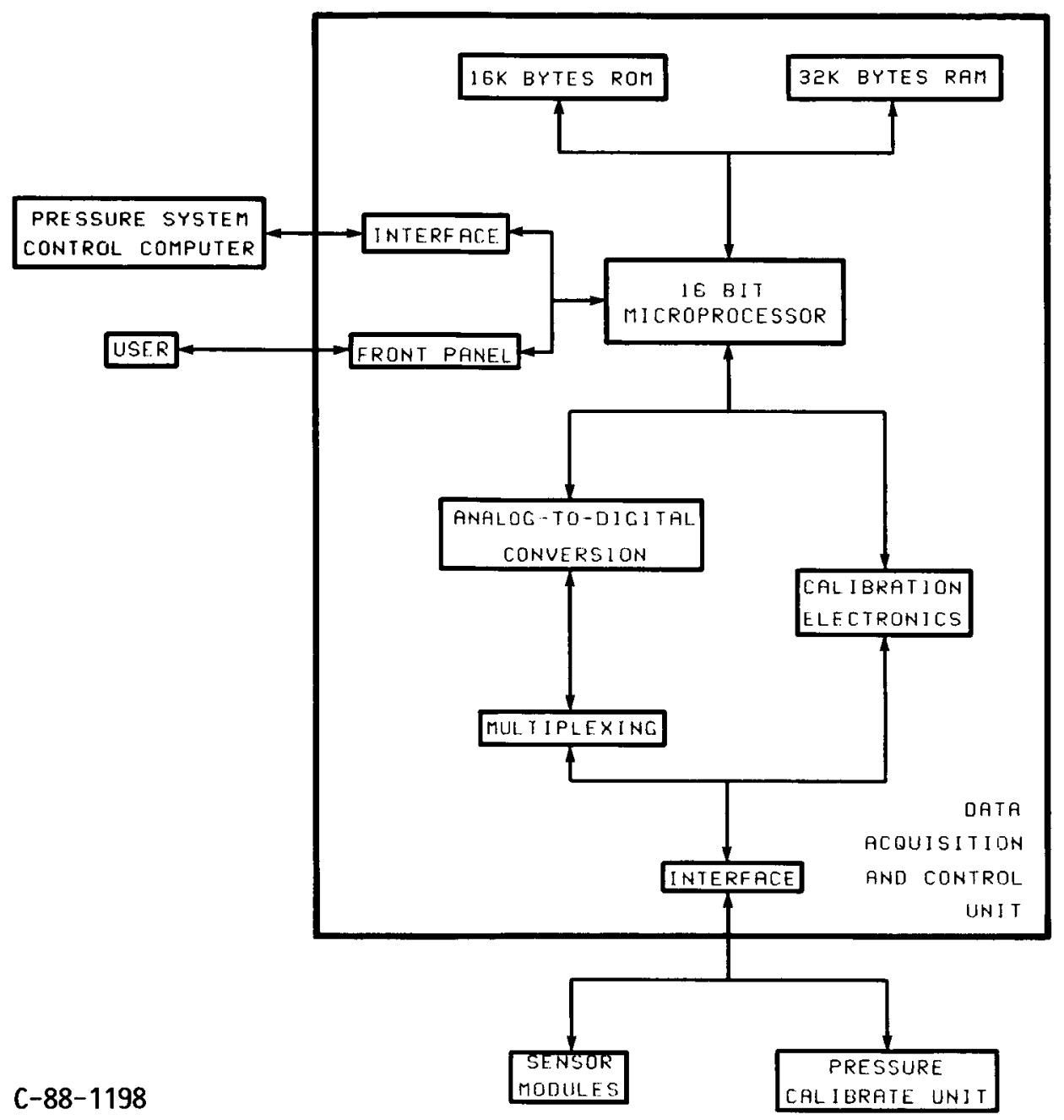

FIGURE 9. - ELECTRONICALLY SCANNED PRESSURE SYSTEM DATA ACQUISITION AND CONTROL UNIT. 


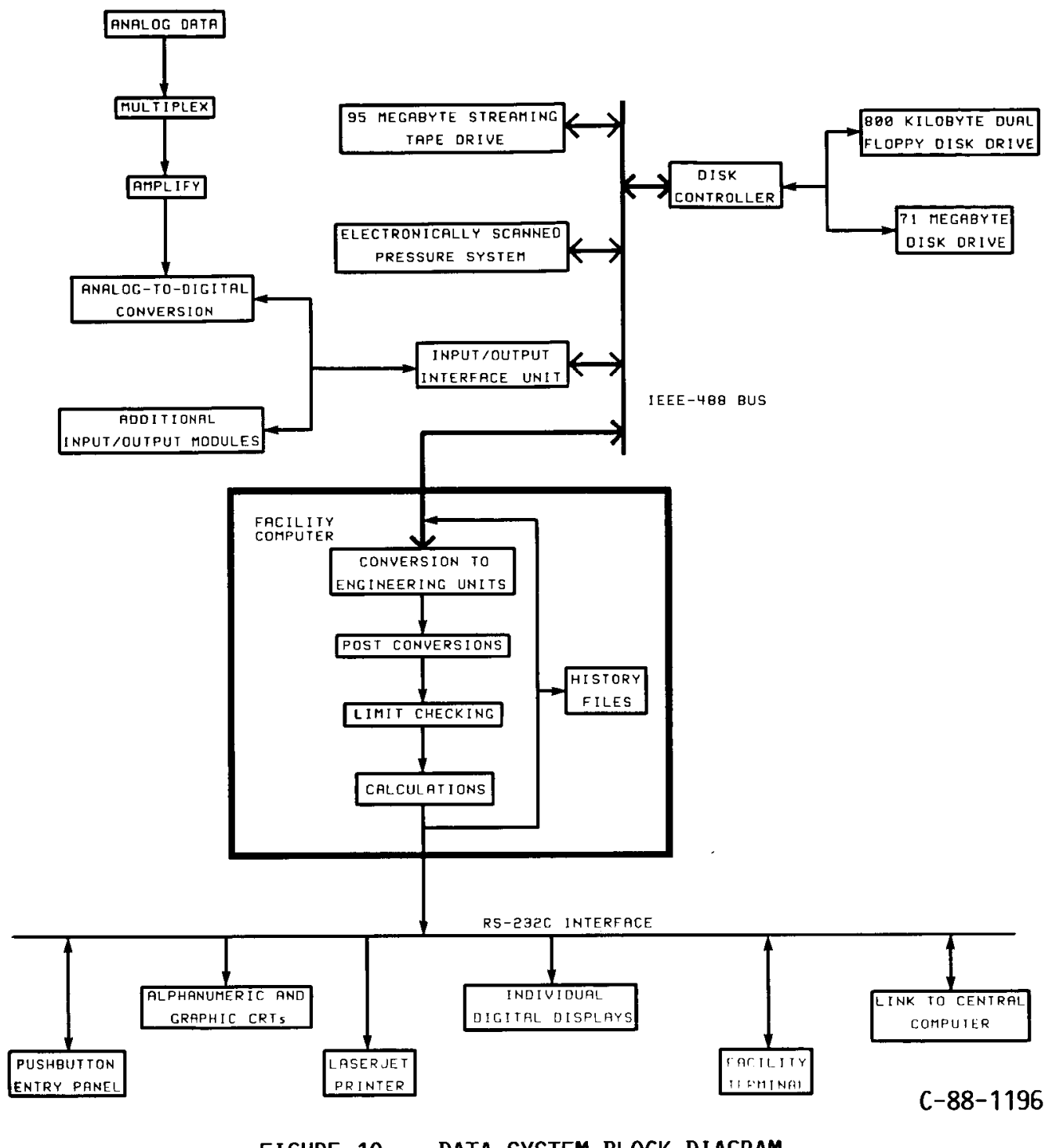

FIGURE 10. - DATA SYSTEM BLOCK DIAGRAM. 
ORGINAT PAGE IS

OF POC' NTIALITY

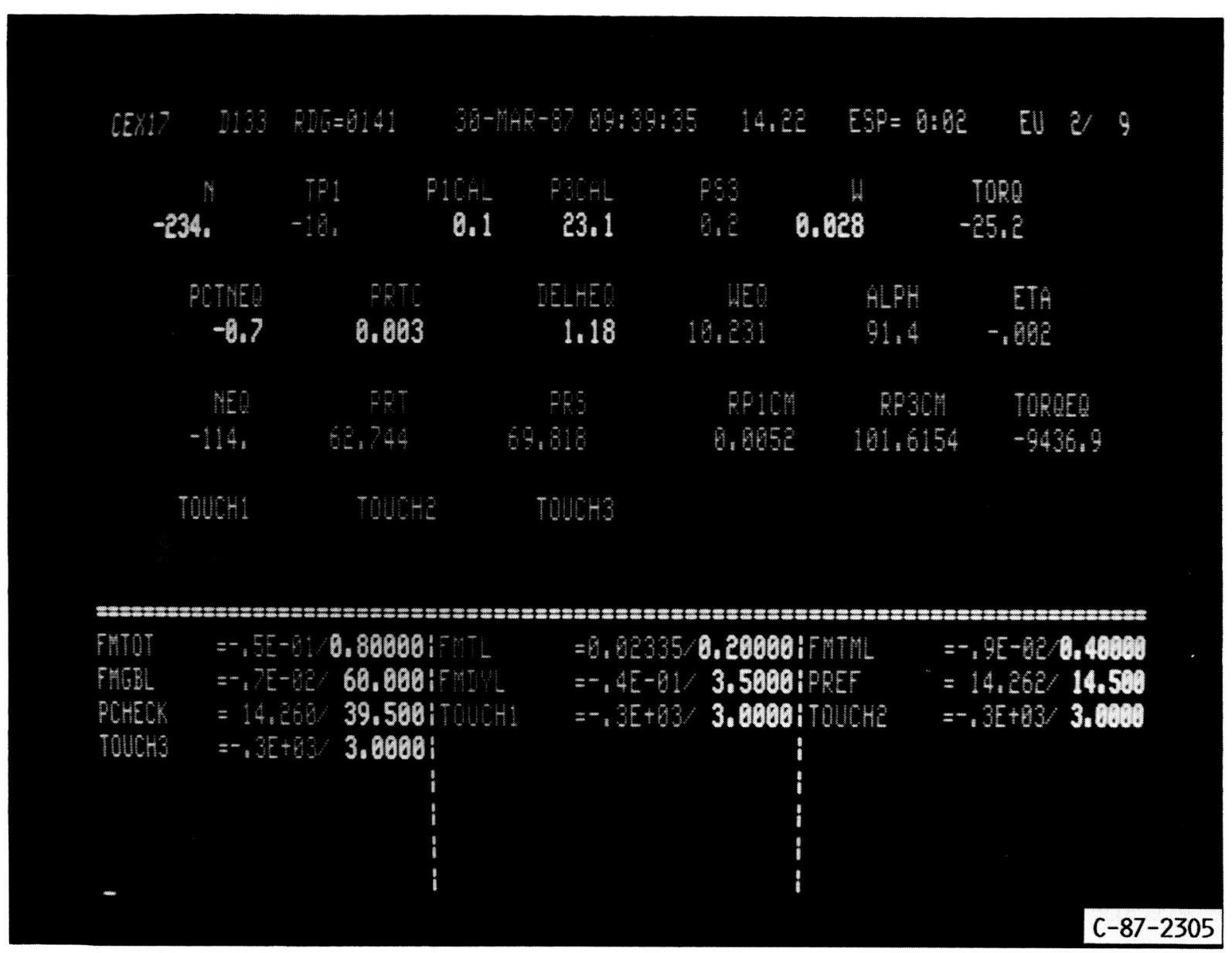

FIGURE 11. - CRT SCREEN WITH CHANNELS IN LIMIT VIOLATIONS. 


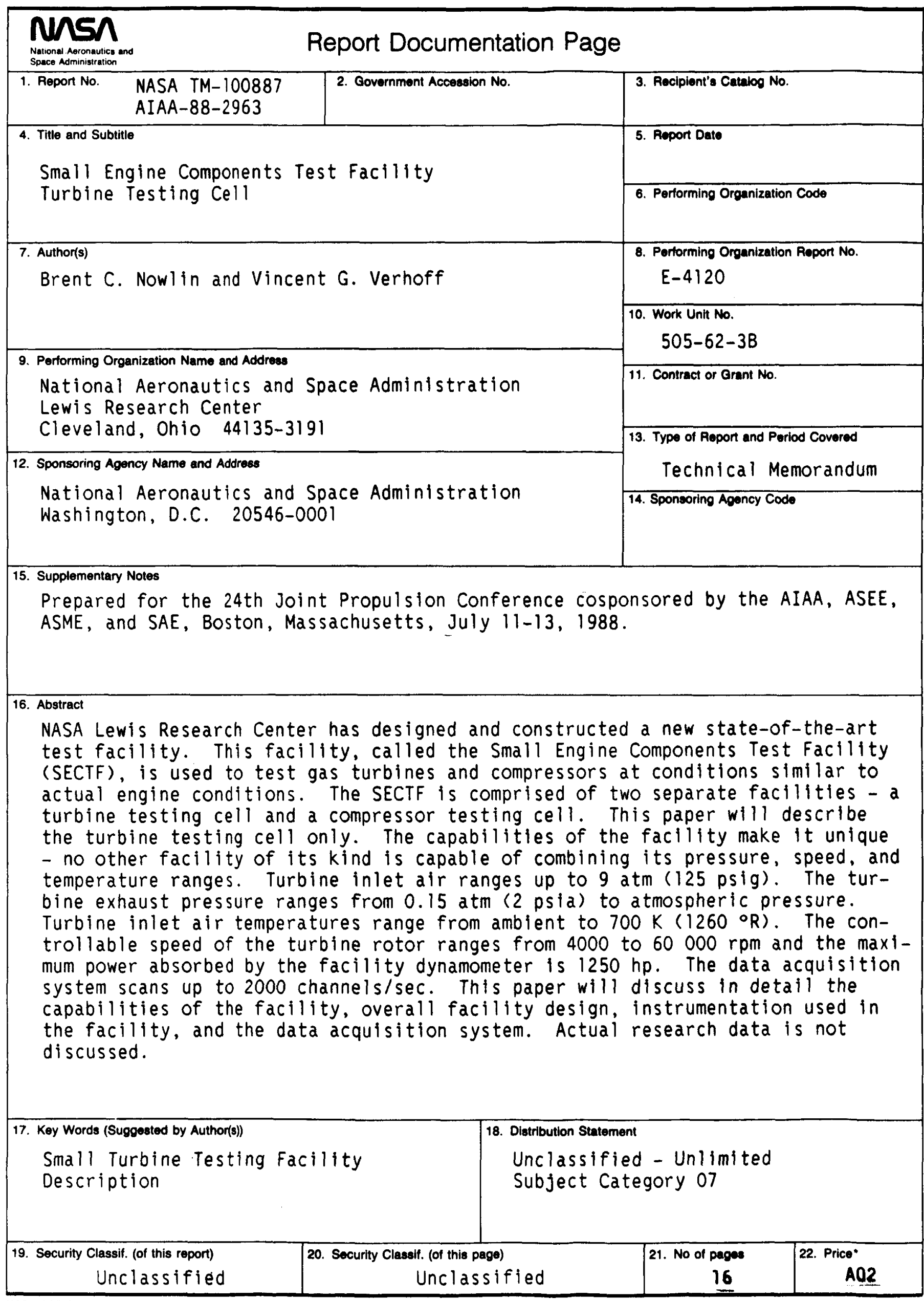

